\title{
The Myth of Creation in William Blake's The Four Zoas
}

\author{
Hossein Moradi
}

\section{ABSTRACT}

Northrop Frye knows the cyclic version of creation myth in his reading of The Four Zoas according to which the human lives in heaven unified with God, unfallen state; he then falls and loses the harmony had with God, fallen state; and he should restore the previous unfallen state in Apocalypse or Last Judgment. Unlike Fry, while thinking of Maurice Blanchot I argue that Blake has created a new myth of creation different from the cyclic one by focusing on what Blake calls Beulah as the stage intermediate between spiritual and physical existence. In the non-original state, Beulah is the state of perpetual creation beyond dialectic and dualism known in Eternity and the life on the earth, a sort of becoming. For Blake, this proves that entities are not created to be manifested in the state of independent selfhood, but they are in relation with the others. This makes both selfhood and indefiniteness simultaneously possible to exist. It is Beulah itself which is all and the only space of existence opening itself from within itself. All entities including God are in interrelationship while being in the process of interruption (acquiring selfhood) within continuation (interrelationship) simultaneously. This demonstrates Blake's new myth of creation avoiding the primal crisis of the cyclic myth of creation. He has also introduced a new idea of relationship.

Keywords: Blake, Beulah, becoming, the cyclic myth of creation, relationship, Maurice Blanchot.

Published Online: July 08, 2021

ISSN: $2736-5514$

DOI : $10.24018 /$ theology.2021.1.3.13

\section{Hossein Moradi *}

English Literature Department, College of Literature and Foreign Languages, Islamic Azad University, Karaj Branch, Alborz, Iran.

(e-mail: moradi.hossein@ ${ }^{\circledR}$ gmail.com)

\section{*Corresponding Author}

\section{INTRODUCTION}

The work of Northrop Frye, Fearful Symmetry (1947), on Blake starts the central phase of mythic readings of Blake in twentieth century. Following Frye, Harold Bloom, Morton Paley, G. E. Bentley, Mary Lynn Johnson and Brian Wilkie are commentators whose interpretations dominate between 1960 and 1980. Most subsequent critics of Blake are indebted to Frye and mostly recognize the cyclic version of creation myth in their readings of The Four Zoas, that is the human lives in heaven unified with God, unfallen state; he then falls and loses the harmony had with God, fallen state; and he should restore the previous unfallen state in Apocalypse or Last Judgment. Blake recreates the structure of the myth which extends mythic archetypes through reading the Bible. According to G. A. Rosso, who reviews the reception history of The Four Zoas, Frye argues that "the Biblical imagination sees the world in purely poetic terms; it humanizes the world by transforming it into a single form with the mythic outlines of Creation, Fall, Redemption, and Apocalypse" [1]. Harold Bloom similarly drives the "dialectic revisionism" from his study of the Kabbalist Issac Luria. This view describes God through tenfold images of the Sefirot which Bloom calls a "progressive" myth of the outward emanation of God's creation. As David Fite reviews Bloom: "The triple rhythm is the process whereby creation endeavors first to contain the radiance of God's name through contraction, then is shattered by the primal force of the deity into a pattern of substitute of vessels, and finally, is able to restore itself in its by now fully human exile through act of mediation 'that lift up and so liberate the fallen sparks of God from their imprisonment in the fallen world" [2]. For Bloom, the Lurianic Kabbalah posits the creation that can be said to be a catastrophe, the primal crisis that leaves people estranged from the divine and forced to encounter the many echoing crises of temporal beings who endeavor to know the primal power of origins while condemned to existence within the prison of merely natural history. Bloom applies this myth of creation to poetic creation including the situation of Romanticism. Romantic poets fail in their attempt to return to the greater power of their precursors. Bloom implies that not only Romantic poets including Blake believe in this cyclic myth of creation but also fail to be rebellious to find their own imaginative strength through which create a new myth of creation. For Bloom and Frye, the primal crisis is that the human is a temporal being who experiences the imprisonment of his fallen state. Below, unlike Frye and Bloom, through reading lines of Blake's The Four Zoas, I argue that Blake has created a new myth of creation different from the cyclic one. To illustrate this new myth, I focus on what Blake calls Beulah. Blake thinks of Beulah as the stage intermediate between spiritual and physical existence. Beulah would not be the origin from where the creation begins but it is the state of perpetual creation beyond dialectic and dualism known in Eternity and the life on the earth, a sort of becoming. To illustrate this idea of becoming, I argue that entities are not created to be manifested in the state of independent selfhood; while any self is independent, it is in relation with the others. In this state, there is the possibility of both selfhood and indefiniteness simultaneously. The relationship continues in 
the process of becoming without ending up with non-dualistic state. It is Beulah itself which is all and the only space of existence opening itself from within itself. All entities including God are in interrelationship. Any entity's existence is in the process of interruption (acquiring selfhood) within continuation (interrelationship) simultaneously. This proves that Blake has thought of the new myth of creation avoiding the primal crisis of the cyclic myth of creation. He has also introduced a new idea of relationship.

\section{BEHULAH}

Blake in The Four Zoas in the Night First introduces Beulah as a dreamy paradise, the state of dreamy innocence that seems to be the condition of passive repose:

There is from Great Eternity a mild \& pleasant rest

Named Beulah a Soft Moony Universe feminine lovely

Pure mild \& Gentle given in Mercy to those who sleep

Eternally. Created by the Lamb of God around

On all sides within \& without the Universal Man

The Daughters of Beulah follow sleepers in all their Dreams

The Circle of Destiny complete they gave to it a Space

And named the Space Ulro \& brooded over it in care \& love [3].

Beulah is the eternal resting space associated with dream. The Lamb of God and the Universal Man dwell in this land. Beulah is the middle state opened through dreams and visions to those who are in Ulro, the fallen world. This middle state imagined for Beulah has been described by Frye: "In the account of 'Eden' in Genesis, the unfallen state of man is presented in terms of Beulah: nothing is left of the flaming city of the sun which Eden must have been" [4]. For Frye, Beulah has an Edenic quality and at the same time the Bible confines its vision to Beulah in its account of the Fall. Beulah is the stage intermediate between spiritual and physical existence, and while it is the dawn and spring for us, the source of inspiration insofar as the arts make use of natural imagery (Blake's Muses are Daughters of Beulah) and the place of seed, from the eternal point of view it is the state of repose and of dormant life [4], p. 232. As Frye continues to describe Beulah, it has two entrances: the north and the south toward which mortals approach from beneath and gods from above [4], p. 232. Blake brings the unfallen (the Edenic life) and the fallen (life on earth) states into Beulah in the bothand system. This system challenges Kathleen Raine who discusses that Beulah is "that inter-world between Time and Eternity" [5]. Frye believes that Beulah is a reservoir of life or place of seed which every form of life dwells in before birth and after death [4], p. 228. Accordingly, when Man lives in Beulah, he is created eternally. It makes us also think that for Blake it is impossible to consider creation outside Beulah.

In Isaiah, 62:4, Beulah, the new place of creation, is presented as a married land: "Thou shalt no more be termed Forsaken; neither shall thy land any more be termed Desolate: but thou shalt be called Hephzibah, and thy land Beulah: for the LORD delighted in thee, and thy land shall be married." In discussing a vision of Beulah, Leopold Damrosch referring to The Four Zoas states: "Christ creates a woman - whereas in Blake's Eden there is no creation, only eternal life - and the Emanation Ahania is reborn through union with Jerusalem, the bride of Christ and maternal Church" [6]. Beulah is the only place where the act of creation occurs through marriage, whereas the Eden is the land of eternal life. Nearly at the end of the Night First in The Four Zoas, the Daughters of Beulah prepare a couch where Jerusalem can sleep while the battle rages in Albion. This is better than having her do mischief under the direction of Enitharmon:

Weeping. the Daughters of Beulah silent in the Porches

Spread her a couch unknown to Enitharmon here reposed

Jerusalem in slumbers soft lulled into silent rest

Terrific raged the Eternal Wheels of intellect terrific raged

The living creatures of the wheels in the Wars of Eternal life

But perverse rolled the wheels of Urizen \& Luvah back reversed

Downwards \& outwards consuming in the wars of Eternal Death [3], p.312].

While on the one side is the battle of Eternal life, there are the wars of Eternal Death on the other side. These battles are the war of negations while Beulah situated between them is the safe place for Jerusalem. Beulah neither belongs to the Eternal life nor to the life of the living creatures on earth upon which Urizen has brought battle. In Beulah, thus, the married land of Jerusalem and Christ, the act of creation occurs while the Edenic life and the life on the earth on both sides are in the war of negations.

Between Eternity and Ulro, Beulah is imagined as the space without conflict: "Beulah is a mitigation of the full consciousness of Eternity; and this is perfectly expressed by the statement that in Beulah 'Contraries are equally true.' That is to say Beulah is a condition between sexual Existence, where Contraries are negations, and Eternity, where Contraries are Contraries and are known to be Contraries" [3], p. 175. The negation of contraries is what Hegel attempted to embody in the structure of dialectic, i.e., the dynamic unity of the contraries. In Eternity where contraries are contraries, Blake embraces the Kantian dualism. However, it is between Eternity and the fallen world (the sexual Existence) where Beulah emerges and Blake goes beyond the Hegelian dialectic and the Kantian division. As Lorraine Clark argues, Blake thinks of creating something between these two which keeps the contraries in order to dissolute them into pure Becoming [7]. This idea can be accorded with Frye's interpretation that "Beulah is the world of those transient intuitions of eternity which are not hammered into definite form" [4], p. 230. Blake recognizes Beulah as the space where existence is the changing stand that never gets definite form, the pure Becoming. Blake, thus, turns to the idea of Beulah - not only Eternity but also the fallen state - as the way toward creating his new myth of 
creation as he says: "I will not Reason \& Compare: my business is to Create" [3]. In this sense, Tony Trigilio argues, Blake must construct a prophetic language while remaining wholly within presumably fallen language. This is the premise behind the creation of Beulah [8].

\section{THE ACT OF BECOMING IN BEULAH}

In Beulah, two modes of life can be experienced. Their contrast can illustrate what I call the creation as the act of becoming. First, if the human acquires an individual identity for him/herself, s/he feels that s/he has fallen from Eden and tries to return there. This would be the cyclic view of the myth of creation. However, Blake contemplates another mode of existence in which the human enters into relationship with God differently in Beulah. In this second mode, the human is not an individual but the state or the fragment which is not part of a whole but in the process of becoming. In Beulah in this condition, fragments come into existence from within Beulah.

\section{A. Urizen}

Nearly at the end of Night Fifth, there is a shift to Urizen's view of his fallen state in contrast with the unfallen state. Urizen misses the unfallen state in heaven. Urizen fears of doing the guilty pleasure or the sensuous pleasure which means for him the passivity. Blake in the last two lines of this night writes: "When thought is closed in Caves. Then love shall shew its root in deepest hell" [3], p. 344.]. According to Kathryn S. Freeman who interprets this line, thought buried in caves anticipates vision at the center of the human. Thought without vision is the deadly power of Urizen in the fallen state. Urizen's act is intended to protect but it becomes self-subverting. Urizen is anxious about creating chaos around an empty center [9]. Thought becomes the sole power to reign over everything. For Jennifer Jesse, this illustrates the inseparability of nature and reason in Urizen. Urizen becomes satanic and the sovereign ruling over this world [10].

In the Night Sixth, Urizen intends to move from chaos to stability and redeem. If Los is forced to betray his inspiration, Urizen is forced to compromise his doubt. Urizen moves toward the community formed based on natural religion not inspiration. Urizen travels in the world of Urthona in search of Orc and begins from West. In his journey, Urizan finds some design in nature. His own vision of the infinite does not threaten the finite material world but is actually dependent on it. However, for Urizen, reason cannot be satisfied with the pleasure of natural appetite. Hence, Urizan finds a sense of alienation in nature: "And taking off his silver helmet filled it $\&$ drank/But when Unsatiated his thirst he assayed to gather more" [3], p. 345. Urizan does not know his daughters when he meets them. His eldest daughter is associated with the Mystery of Revelation. The second daughter associates with Virgin Mary. His third one clothed in green color is associated with Venus, natural fertility, and envy. The daughters' appearance reflects that nature is governed by mysterious forces. When the moment of recognition between parents and children comes, they withdraw from the creative involvement with the world. Following this withdrawal,
Urizen curses his children: "That they may curse Tharmas their God \& Los his adopted son/That they may curse \& worship the obscure Demon of destruction" [3], pp. 45-6. According to Andrew Lincoln commenting on the lines: "Having acknowledged the supremacy of Tharmas, reason now must enter chaos and confront the full horror of a godless materialism, as Los did in the night IV. Los and Enitharmon inspired love and pity, but Urizan views the world as coldly as possible" [11]. As Urizen goes on, he withholds his light because he confronts the realm of ever-shifting impressions that seems always to elude final definition. Here the confrontation between reason and the material world happens. In this world, Urizen finds no hope for constructive action. From now on, Blake reflects that the responsibility for shaping Man's future has passed from Los to Urizen, who is the only power free to act. However, Urizen is no longer a warrior, but an observer: "And saw their grizzly fears \& his eyes sickened at the sight/The howling's gnashing's groanings shrieking's shuddering's sobbing bursting" [3], p. 346. What Urizen observes remains unknown and can only be judged through its external appearance. Until he confronts directly Orc, Urizen can have no experience of the infinitive vision of desire but sees only the disastrous external consequences of raging natural appetite. He goes toward East, the empty world of Luvah. He creates something to redeem him, which is the Divine hand. The renewal of life must be continued, and the wisdom depends on this. But Man is always subject to the condition he observes. There is no fixed external vantage point based on which he can have a rational interpretation. That is why, As Blake Hobby explains, Urizen is filled with interpretation anxiety [12]. Blake creates the idea of vortex to dramatize this dilemma. It has been related to Cartesian physics. The vortex leads into confusion because of the limited systems of orders:

Creating many a Vortex fixing many a Science in the deep And thence throwing his venturous limbs into the Vast unknown

Swift from Chaos to chaos from void to void a road immense

For when he came to where a Vortex ceased to operate Nor down nor up remained then if he turned \&looked back From whence he came taws upward all. \& If he turned and viewed

The unpassed void upward was still his mighty wandering. [3], p. 349.

According to Freeman, he is anxious about creating chaos around the empty center [9], p. 118. Later, Urizen is wearied from the search for an external vantage point. He decides to find a point in the abyss. This is the point where the natural philosophy becomes methodical. He once more becomes the source of wisdom. As Urizen travels through darkness, he sees the Web of Spider behind him. It is associated with the faith that motivates empirical science. But the web is an illusion and is broken. Man is limited to his horizon and cannot comprehend truth. Urizen is the philosopher who generates his own myth [3], p. 59. Here, Urizen again begins to move toward a conception of eternal life, as it is believed a divine creator exists beyond the closed world of senses. 
But in Night Seventh, this time Urizen forgetting the divine creator declares himself as God and controls other creatures. Blake writes that Urizen grows up in Beulah: "Urizen grew up in the plains of Beulah Many Sons/And many daughters flourished round the holy Tent of Man/Till he forgot Eternity delighted in his sweet joy/Among his family his flocks \& herds \& tents $\&$ pastures" [3], p. 358. Urizen enslaves others. Until Urizen controls others, the moneyness does not make the fallen state to begin. Urizen creates a false unity and does not let others their separation form Eternity. Urizen now as God who has not been able to find an external center commands his sons to build a center:

And he commanded his Sons found a Center in the Deep And Urizen laid the first Stone \& all his myriads

Built a temple in the image of the human heart

And in the inner part of the Temple wondrous workmanship

They formed the Secret place reversing all the order of delight

That whosoever entered into the temple might not behold The hidden wonders allegoric of the Generations [3], p. 361.

Urizen began his journey by distancing himself from the world in order to bring order into the chaotic world he sees. He feels he needs to know the creator or the Divine hand to help him. But he did not act to enter into relationship with God; he became only an observer whose power of reason failed to see truth. Now he begins another mode of relationship. He himself is God and creator. He actually centralizes himself.

He brings a religion of division by separating entities from one another: "Crying As I will I rend the Nations all asunder rending/The People, vain their combinations I will scatter them" [3], p. 361. Tharmas speaks of a crystal form in his bosom which refers to the center which Urizen built already. Urizen himself functioning as the center makes a web: "Thro all the heavens Urizens Web vibrated torment on torment" [3], p. 363. This web restrains others. For Urizen, according to David Fuller, "fixity is preferable to flux, uniformity to variousness" [13]. Orc who is trapped in this web manages to free himself:

No more remained of Orc but the Serpent round the tree of Mystery

The form of Orc was gone he read his serpent bulk among The stars of Urizen in Power rending the form of life

Into a formless indefinite \& strewing her on the Abyss [3], p. 65 .

In a sense, he decentralizes himself since the state of division made by Urizen has been built on a sort of centralization. He is no longer the creature holding an individuated identity, but he is the amorphous state of existence flouting in the flux of existence. As Laura Quinney discusses Blake's Milton, "the Selfhood is a misconstruction of the self, an ill-fated and delusory fragment falsely representing itself as the whole" [14]. The nature of Urizen's web is revealed when we see Los embraced his Spectre. The
Spectre speaking to Los believes that anybody is split within itself if he is the slave of passion. The Spectre claims that he is Los's real self not another self. He should be one with him. It implies that Urizen has made the Spectre to give a centralizing selfhood to human. The end of this spectrous selfhood is death in the Lake of Udan Adan: "Then myriads of the Dead burst through the bottoms of their tombs/Descending on the shadowy females clouds in Spectrous terror/Beyond the Limit of Translucence on the Lake of Udan Adan" [3], p. 367. According to S. Foster Damon, the lake is the condition of formlessness. This lake is formed from the victims of Urizen's laws [15]. Urizen generates a cyclic movement from formlessness into division ending up with the formlessness. In other words, the process begins with unity, transforms into moneyness and turns into a deadly unity. For Blake, this is a false process. It does not signify that Blake is looking for a truthful harmony, since after these lines Los reflects a self/other opposition and removes the Spectre's view by entering into another relationship with others. Los loses his selfhood to embrace the other. This is not nondualism or dialectic to turn toward wholeness as Freeman discusses [9], p. 33. I will argue below that this opposition eradicates the spectrous selfhood in Beulah to begin the act of becoming.

\section{B. The New Relationship}

This new relationship is the beginning of what Blake introduces as the second mode of life and his new mythology of creation. Urizen failed two times. Or generally speaking the human has failed in his relationship with God and the world in his life on earth. First, once he sees God as the creator outside himself and is unsuccessful to acknowledge it. The second, when he calls himself God, the center. Blake creates a new space within Beulah named Golgonooza. Since Los has rejected the spectrous selfhood, he feels a world is opened within his bosom: "Even I already feel a World within/Opening its gates \& in it all the real substances/Of which these in the outward World are shadows which pass away/Come then into my Bosom \& in thy shadowy arms bring with thee/My lovely Enitharmon" [3], p. 368. Here while Los has rejected the selfhood and he is formless there is the proliferation of bodies, heavens, and atmosphere: "Domes terrific in the nether heavens for beneath/Was opend new heavens \& a new Earth beneath \& within/Threefold within the brain within the heart within the loins/A Threefold Atmosphere Sublime continuous from Urthonas world/But yet having a Limit Twofold named Satan \& Adam" [3], p. 368. In this state, there are the possibilities of both the selfhood and the indefiniteness simultaneously which illustrate a new kind of relationship: "That vanish again into my bosom but if thou my Los/Wilt in sweet, moderated fury fabricate forms sublime/Such as the piteous spectres may assimilate themselves into" [3], p. 370. In the view of Bloom, in Beulah, "the form dies, and the substance is liberated to find a fresh form" [16]. This is in contrast with the dialectic Urizen's laws have made. Urizen believes that the dialectic is impossible without a center: "Steeping the Direful Web of Religion swagging heavy it fell/From heaven to heaven through all its meshes altering the Vortexes/Misplacing every Center hungry desire \& lust began/Gathering the fruit of that Mysterious tree" [3], pp. 375-76. In Urizen's model of 
dialectic, any time the center changes. This is the structure of unity which is not possible without a center. According to Maurice Blanchot who defines similar kind of relationship different from dualism and dialectic, "this relation does not turn toward unity, it is not a relation from the perspective of unity or with unity in view, not a relation of unification. The One is not the ultimate horizon, any more than is Being, thought always as the continuity, the gathering, or the unity of being" [17]. The limit of Satan \& Adam blinds the human to see there is no central unification diffused by division, but there is the state of independency for each fold, that is "Contraries are equally true." However, these tree parts come into the new relationship without centralization of any of them. This decentralized state is not found in the idea of the nondualism and the dialectic. As Susan Fox argues, this is the paradox of Blake's cosmology. According to her, "the more its divisions become, the more profoundly interinvolved they become" [18]. Beulah and Golgonooza have been created to show this condition.

Following the opening of the new world, the Spectre of Urthona becomes the medium to relate Los and Enitharmon. This is the beginning of the new relationship between two selves. The Spectre of Urthona confesses that he began the dreadful state of separation. The Spectre regrets and accepts that there should be the relationship among selves and each self is the counterpart to another self. Here, the idea of single selfhood changes. In the new state of selfhood, while any self is independent, it is in relation with others. However, this relationship is different, since none of the selves are playing the role of center: "For Los could enter into Enitharmons bosom \& explore/Its intricate Labyrinths now the Obdurate heart was broken" [3], p. 372. Enitharmon's heart in Golgonooza becomes flexible and its labyrinth's condition is enabled to be explored by Los. While they are the two selves divided, they explore each other returning them neither to themselves nor to the One. Blanchot similarly argues this kind of relation. He invites us to try "to speak in referring to the Other without reference to the One and without reference to the Same" [17], p. 68. In this kind of relation, according to Blanchot, "the Other, the presence of the other, would return us neither to ourselves nor to the One" [17], p. 67. In a neither/nor condition, Blanchot explains, it is a mobileimmobile relation, untold and without number, not indeterminate but indetermining, always in displacement, being without a place, and such that it seems to draw-repel any "I" into leaving its site or its role-which, nonetheless, the "I" must maintain, having become nomadic or anonymous in an abyssal space of resonance and condensation [17], p. 68.

In Night Ninth, the Lamb of God in Jerusalem, which Blake earlier located it in Beulah, in a "self-renewing vision" split himself into two halves: "Thus shall the male \& female live the life of Eternity/Because the Lamb of God Creates himself a bride \& wife/That we his Children evermore may live in Jerusalem" [3], p. 67. In Jerusalem in Beulah, the Lamb of God representing the state of perfect man renews himself from within through creating a counterpart, an other, in order that the relationship is established. According to Blanchot, the "I" transforms into something other than what he/she is perpetually. The volcanic interruption of here and now holds the "I" in always already caesura, an interruption.
The human becomes what is "most distant from man, coming toward him as what is irreducibly Distant: in this sense, far more separated from him than he is from the limit of the Universe or than he would be from God himself" [17], p. 68. The human is as such the Distant meaning neither closure nor separation. This relationship is different from the state of satanic multitude. Here the self enters into relation with itself as the other without becoming an individual identity. The relationship continues in the process of becoming without ending up with the nondualistic or the dialectic state of being.

\section{CONCLUSION}

According to Maurice Blanchot, the human experiences three sets of relations. In the first "reigns law of the same. Man wants unity, he observes separation" [68]. While the human separates itself from any other things, it converts them into some other thing identical to him/herself. The separation accounts for the point that things are not distinguished as different individual entities but the same. They are the outcome of the act of the repetition reducing differences into the same; as such things are different but the same, the repetition of the same as Walter Benjamin implies in "The Work of Art in the Age of Mechanical Reproduction" [19]. God would not also be known as the One or the Other. Neither one nor multiplicity characterizes this kind of relationship. In the second kind of relation, the human is still seeking unity, unlike the first one converting the other into the self-same, with something other than him/herself but no longer in the sovereign position of "I" in this relation. Rather, the Other is sovereign and the absolute being, no more than a substitute for the One. This desire for the One presupposes the demand for the oneness of being. Although the "other" is absolute, it is a stage for the Subject to leave behind to arrive in the final oneness. This dialectic relation is closed upon itself in order to constitute a homogeneous being. This self-other relationship does not disrupt the subject's self-enclosure and does not undermine the sufficiency of the subject's rational thought. The rigor of the self-other relation and of the One hold thought captive in the ideas of separation, jointure and continuation. Depending on or being independent from something other stands for the solitude or non-interiority of the self which is exposed by the relation with the outside. Thus, absorbing otherness into oneness denotes the fear of the "other" and it never gets to the fear for the "other" in which the menace of his mortality is not construed as the menace of an encounterable force.

In the third kind of relationship, Blake's non-cyclic myth of creation builds Golgonooza in Beulah to open a middle state which is the only space exists. God and creation occur in this space. The human does not follow Urizen's law to see himself as an autonomous individual who reduces God to his own subjectivity. Urizen calls himself God but fails to dominate his self-same law. Moreover, in Beulah the human never thinks of himself as the autonomous state in the fallen state struggling to reunify with God who is One. The new self-other vision in Golgonooza opens new worlds within itself which implies that nothing occurs outside Beulah. The human is not the agent of this opening. It is Beulah itself which is all and the only space of existence opening itself 
from within itself. Thus, we cannot claim that everything happens in the human mind. This new vision provokes the idea that God and every other entity have been always already inseparable. In this view, Blake goes beyond nondualism. All entities including God are in interrelationship. In this state, Blake does not see separation but imagines existence in the process of interruption within continuation simultaneously. Existence comes to stand in fragmentary state while continues to become. The human becomes the event of singularity not the same as autonomy, oneness, particularity, identity, contingency, or specificity; nor does it simply refer to the entity which is unlike all other entities. Thus, it does not mean uniqueness.

\section{REFERENCES}

[1] Rosso, G. A., Blak's Prophetic Workshop: A Study of the Four Zoas, New Jersey: Associate University Press, 1993, p. 36.

[2] Fites, David, Harold Bloom: The Rhetoric of Romantic Vision, Amherst: The University of Massachusetts Press, 2009, p. 65.

[3] Blake, William, The Complete Poetry and Prose of William Blake, Ed. David V. Erdman, California: University of California Press, 2008.

[4] Fry, Northrop, Fearful Symmetry, A Study of William Blake, Princeton: Princeton University Press, 1990, p. 231.

[5] Raine, Kathleen, Golgonooza, City of Imagination: Last Studies in William Blake, New York: Lindisfarne Press, 1991, p. 63.

[6] Damrosch Jr. Leopold, Symbol and Truth in Blake's Myth, Princeton: Princeton Universit Press, 2014.

[7] Clark, Lorraine, Blake, Kierkegaard, and the Spectre of Dialectic, Cambridge University Press, 1991, pp. 48-49, 231.

[8] Trigilio, Tony, "Strange Prophecies Anew": Rereading Apocalypse in Blake, H.D., and Ginsberg, London: Associate University Press, 2000, p. 69.

[9] Freeman, Kathryn S., Blake's Nostos: Fragmentation and Nondualism in The Four Zoa, New York: State University of New York Press, 1997, p. 117.

[10] Jesse, Jennifer, William Blake's Religious Vision: There's a Methodism in His Madness, Plymoth: Lexington Books, 2013, p. 90.

[11] Lincoln, Andrew, Spiritual History: A Reading of William Blake's Vala, Or The Four Zoas, Oxford: Clarendon Press, 1995, p. 130.

[12] Hobby, Blake, "Urizen and the Fragmentary Experience of Sublime in The Four Zoas," in The Sublime, Ed. Harold Bloom, New York: Bloom's Literary Criticism, 2010, p. 58.

[13] Fuller, David, Blake's Heroic Argument, New York: Routledge. 2016, p. 83.

[14] Quinney, Laura, William Blake of Self and Soul, Massachusetts: Harvard University Press, 2009, p. 63.

[15] Damon, Samuel Foster, A Blake Dictionary: The Ideas and Symbols of William Blake, Hanover: Dartmouth College Press, 2013, p. 416.

[16] Bloom, Harold, The Visionary Company: A Reading of English Romantic Poetry, New York: Cornell University Press, 1971, p. 28.

[17] Blanchot, Maurice, The Writing of the Disaster, trans. Ann Smock, London: University of Nebraska Press, 1986, p. 67.

[18] Fox, Susan, Poetic Form in Blake's MILTON, Princeton: Princeton University Press, 1976, p. 210.

[19] Benjamin,Walter, Illuminations, trans. by Harry Zohn, London: Fontana Press, 1992, p. 211. 